\title{
Development of the UV Spectrophotometric Method of Azithromycin in API and Stress Degradation Studies
}

\author{
Sandip Bhimani $i^{1, a}$, Gaurav Sanghvi ${ }^{1, b}$, Trupesh Pethani ${ }^{1, c}$, Gaurav Dave ${ }^{2, d}$, \\ Vishal Airao ${ }^{1,}$, Tejas Sharma ${ }^{1, f}$, Navin Sheth ${ }^{1, g}$, Devendra Vaishnav ${ }^{*}, 1, \mathrm{~h}$ ' \\ ${ }^{1}$ Department of Pharmaceutical Sciences, Saurashtra University, Rajkot - 360 005, Gujarat, India \\ ${ }^{2}$ Department of Biochemistry, Saurashtra University, Rajkot - 360005 Gujarat, India \\ asandip_pharma@ymail.com, bgv.sanghvi@gmail.com, ctrupeshpharma@gmail.com, \\ 'gsdspu@gmail.com, ${ }^{\mathrm{e}}$ vishal.airao@gmail.com, ${ }^{\mathrm{f}}$ sharmatejas87@gmail.com, \\ gnavin_sheth@yahoo.com, hdevvaishnav@gmail.com \\ * Corresponding author's address \\ Department of Pharmaceutical Sciences, Saurashtra University Campus, \\ Rajkot - 360005 Gujarat, India \\ TeleFax: +91-281-2585083
}

Keywords: Estimation, Azithromycin, Spectroscopy, Stress degradation study.

\begin{abstract}
Azithromycin (AZI) is a semi-synthetic macrolide antibiotic drug, effective against a wide variety of bacteria. The present study describes a simple, accurate, reproducible and precise UV Spectrophotometric method for the estimation of AZI ( $\mathrm{pH} 6.8$ Phosphate buffer). The absorbance maximum $\left(\lambda_{\max }\right)$ for AZI was found to be $208 \mathrm{~nm}$. The method reveals high sensitivity, with linearity in the $10 \mu \mathrm{g} / \mathrm{ml}$ to $50 \mu \mathrm{g} / \mathrm{ml}$ range. The lower limit of detection was found to be $1.6 \mu \mathrm{g} / \mathrm{ml}$ and the limit of quantification was found to be $5 \mu \mathrm{g} / \mathrm{ml}$. All the calibration curves demonstrated a linear relationship between the absorbance and concentration, with the correlation coefficient higher than 0.99 . The $\%$ recovery was found to be $99.72 \%$. AZI was also subjected to stress degradation under different conditions recommended by the International Conference on Harmonization ( $\mathrm{ICH})$.
\end{abstract}

\section{Introduction:}

Azithromycin (AZI) is chemically known as (2R,3S,4R,5R,8R,10R,11R,12S,13S, 14R)-2-ethyl$3,4,10$-trihydroxy-3,5,6,8,10,12,14-heptamethyl-15-oxo-11-\{[3,4,6-trideoxy-3-(dimethylamino)- $\beta$ D-xylo-]oxy\}-1-oxa-6-azacyclopentadec-13-yl2,6-dideoxy-3-C-methyl-3-O-methyl- $\alpha$-L-ribo-hexopyranoside (figure 1), is a broad spectrum semi-synthetic marcolide antibiotic, called azalides. According to Amantea and co-workers AZI protects mice against ischemic stroke injury by promoting macrophage transition towards M2 phenotype [1]. The chemistry, mechanism of action, antimicrobial spectrum, pharmacokinetics, clinical efficacy, adverse effects, drug interactions, and dosage and administration of AZI were described by elsewhere [2]. Foulds and co-workers studied the pharmacokinetics of AZI and found that approximately $37 \%$ of a single oral dose of $500 \mathrm{mg}$ was bioavailable and produced a peak serum concentration of $04 \mathrm{mg} / \mathrm{L}$ while, multiple dose regimens produced only slight increases in peak serum concentrations [3]. Mendic and co-workers investigated the electrochemical oxidation of AZI in order to elucidate the mechanism for possible oxidative metabolic pathways in humans [4]. Various methods were proposed to estimate the AZI for both plasma and non-plasma medium like voltammetric assay [5], HPLC [6-8], HPTLC [9], LC-MS [10,11], LC-MS/MS [12]. Present study is aimed to develop a selective, precise, accurate and reliable UV method for determination of AZI. 


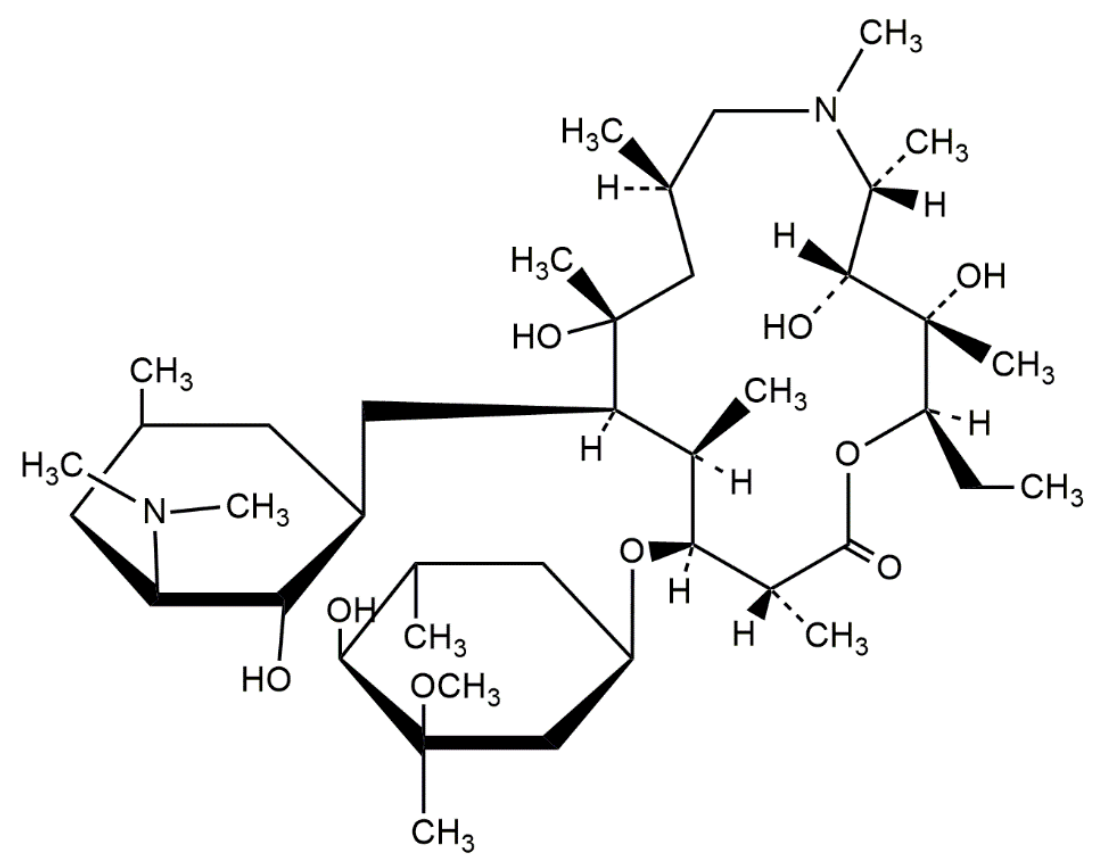

Figure 1: Chemical structure of azithromycin

\section{Materials and methods}

\section{Instruments and reagents}

For spectral measurements, Shimadzu UV/VIS double beam spectrophotometer (model 1800) with $1 \mathrm{~cm}$ matched quartz cells was used. Shimadzu AX200 analytical balance was used for the weighing purpose. For robustness study Shimadzu (model 1700) was used. The API use was kindly gifted by Nectar Drugs Pvt. Ltd., Mumbai, India. Marketed formulation of Azithromycin used for the specificity study was purchased from local market (AZIPHAR $250 \mathrm{mg}$ tablet). All other chemicals were of analytical grade.

\section{Preparation of standard stoke solution (SSS) and working standard solutions (WSS)}

Accurately weighed $10 \mathrm{mg}$ of AZI was transferred to a $10 \mathrm{~mL}$ volumetric flask and volume was made up with the $0.1 \mathrm{~N} \mathrm{HCl}$ to get SSS of concentration $1000 \mu \mathrm{g} / \mathrm{mL}$. From the SSS $1 \mathrm{~mL}$ was drawn out and diluted with pH 6.8 phosphate buffer up to $10 \mathrm{~mL}$ to get a WSS having concentration of $100 \mu \mathrm{g} / \mathrm{mL}$ and then further dilutions were made to obtain the concentration range of $10-50 \mu \mathrm{g} / \mathrm{mL}$ using $\mathrm{pH} 6.8$ phosphate buffer as a solvent.

Phosphate buffer ( $\mathrm{pH}$ 6.8) was prepared by taking $50.0 \mathrm{~mL}$ of $0.2 \mathrm{M}$ potassium dihydrogen phosphate in a $200 \mathrm{~mL}$ volumetric flask, subsequently $22.4 \mathrm{~mL}$ of $0.2 \mathrm{M}$ sodium hydroxide was added and then volume was make up with $\mathrm{D} / \mathrm{W}$ water. Filter if necessary with whatman filter paper.

\section{Determination of wavelength of maximum absorption}

An UV spectroscopic scanning (200 - $400 \mathrm{~nm}$ ) was carried out with the WSS solution to determine the $\lambda \max$ for the detection of AZI using Phosphate buffer (pH 6.8) as blank.

\section{Analytical method validation}

Validation is a process of establishing documented evidence, which provides a high degree of assurance that a specified method will consistently produce a desire result, or a product meeting its predetermined quality. The method was validated for different parameters like linearity, specificity, selectivity, accuracy, precision, robustness, ruggedness, limit of quantification (LOQ) and limit of detection (LOD) as per the guideline prescribed by International conference on Harmonization (ICH) [13].

\section{Linearity}

The sample was analysed using UV-VIS spectrophotometer, using phosphate buffer $\mathrm{pH} 6.8$ as a blank. The linearity of the AZI was studied using range of dilution of 10, 20, 30, 40, and $50 \mu \mathrm{g} / \mathrm{mL}$. All experiments were performed in triplicate. 


\section{Accuracy}

The accuracy of the method was determined by preparing solution of different concentrations, that is $80 \%, 100 \%$, and $120 \%$, in which the amount of marketed formulation was kept constant $(30 \mathrm{mg}$ ) and the amount of pure drug was varied, that is, $24 \mathrm{mg}, 30 \mathrm{mg}, 36 \mathrm{mg}$ for 80 , 100 , and $120 \%$, respectively. All experiments were performed in triplicate.

\section{Precision}

The precision of method was performed by intra-day and inter-day variation studies. In the intra-day variation study, six different solution of same concentration $(30 \mu \mathrm{g} / \mathrm{mL})$ were prepared and analysed thrice a day (morning, afternoon, evening) and the absorbance were recorded. In interday variation study, the six different solution of same concentration $(30 \mu \mathrm{g} / \mathrm{mL})$ were prepared and analysed thrice, for three consecutive days, and the absorbance were recorded. All experiments were performed in triplicate.

\section{Specificity}

Specificity method was determined by preparing $10 \mathrm{mg}$ of AZI solution in phosphate buffer (pH 6.8) along with 50\% (5 mg), 100\% (10 mg), and 150\% (15 mg) of excipients. All the solutions were prepared and analysed for any change in absorbance and percentage drug recovery at respective wavelengths.

\section{Ruggedness}

The ruggedness of the method was determined by carrying out the analysis using two different analysts and the respective absorbance were noted.

\section{Robustness}

The ruggedness of the method was determined by using two different instruments and the linearity was taken.

\section{Limit of detection}

The limit of detection (LOD) was determines by preparing solutions of different concentrations ranging from $0.01-0.1 \mu \mathrm{g} / \mathrm{mL}$. The detection limit of an individual analytical procedure is the lowest amount of analyte in a sample, which can be detected, but not necessarily quantitated as an exact value.

\section{Limit of quantification}

The limit of quantitation (LOQ) is the concentration that can be quantitated reliably with a specified level of accuracy and precision. The LOQ was calculated using the formula involving the standard deviation of response and the slope of the calibration curve.

\section{Degradation studies}

The ICH guidelines entitled stability testing of new drug substances and products that required stress testing to be carried out to elucidate the inherent stability characteristics of the active substance. The aim of this study was to perform the stress degradation studies on Azithromycin using the method developed.

\section{Stress degradation by acid hydrolysis}

From the stock solution take $3 \mathrm{ml}$ of solution in $10 \mathrm{~mL}$ volumetric flask and add $1 \mathrm{~mL}$ of $1 \mathrm{~N} \mathrm{HCl}$ and make up the volume with methanol. Kept aside for $90 \mathrm{~min}$ in normal condition. After 30 min time interval $1 \mathrm{~mL}$ of sample was taken out and diluted to achieve a concentration of 30 $\mu \mathrm{g} / \mathrm{mL}$. For the blank solution $0.5 \mathrm{~mL}$ of $1 \mathrm{~N} \mathrm{HCl}$ and $0.5 \mathrm{~mL}$ of $1 \mathrm{~N} \mathrm{NaOH}$ were mixed in $10 \mathrm{~mL}$ volumetric flask and dilute up to the mark with phosphate buffer. Repeat the procedure for three times at an interval of $30 \mathrm{~min}$.

\section{Stress degradation by alkaline hydrolysis}

From that SSS take $3 \mathrm{~mL}$ of solution in $10 \mathrm{~mL}$ volumetric flask and add $1 \mathrm{~mL}$ of $0.1 \mathrm{~N}$ $\mathrm{NaOH}$ and make up the volume with methanol. Kept aside for $90 \mathrm{~min}$ in normal condition. After $30 \mathrm{~min}$ time interval $1 \mathrm{~mL}$ of sample was taken out and diluted to achieve a concentration of $30 \mu \mathrm{g} / \mathrm{mL}$. For the blank solution $0.5 \mathrm{~mL}$ of $0.1 \mathrm{~N} \mathrm{NaOH}$ and $0.5 \mathrm{~mL}$ of $0.1 \mathrm{~N} \mathrm{HCl}$ were mixed in $10 \mathrm{~mL}$ volumetric flask and dilute up to the mark with phosphate buffer. Repeat the procedure for three times at an interval of 30 minutes. 


\section{Degradation induced by dry heat}

The AZI powdered drug is kept in petri plate at $70{ }^{\circ} \mathrm{C}$ for $48 \mathrm{hrs}$. After that weigh accurately $10 \mathrm{mg}$ of drug from the sample and dilute with phosphate buffer to get the final concentration $30 \mu \mathrm{g} / \mathrm{mL}$ and analyse by previously validated UV method in triplicate.

\section{Oxidative degradation}

In a $10 \mathrm{~mL}$ of volumetric flask add mix $1.5 \mathrm{~mL}$ of SSS with $1 \mathrm{~mL}$ of $30 \%(\mathrm{v} / \mathrm{v})$ of hydrogen peroxide and dilute up to the mark with methanol. Kept aside for overnight at room temperature. For blank solution, $1 \mathrm{~mL}$ of $30 \% \mathrm{w} / \mathrm{v}$ of hydrogen peroxide was kept under normal condition, overnight in a $10 \mathrm{~mL}$ volumetric flask. Both solutions were heated for $15 \mathrm{~min}$ to remove excess of hydrogen peroxide and analyse with UV.

\section{Degradation by UV}

A sample of azithromycin was kept near to UV in a stability chamber for $12 \mathrm{hrs}$, providing the illumination not less than 1.2 million lux hrs. From that sample $10 \mathrm{mg}$ of drug is dissolve in a $10 \mathrm{ml}$ of volumetric flask with $\mathrm{HCl}$ and then make up the volume with buffer solution. Make the dilution with methanol of $30 \mu \mathrm{g} / \mathrm{ml}$ and analyse in UV.

\section{Result and discussion}

SSS of AZI was prepared in $\mathrm{HCl}$ because AZI was not completely soluble in $\mathrm{pH} 6.8$ phosphate buffer, while rest of the WSS was prepared using SSS and further dilution with phosphate buffer. UV spectrum of AZI shows $\lambda \max$ at $208 \mathrm{~nm}$ (Figure 2), hence rest of the experiment were performed at $208 \mathrm{~nm}$.

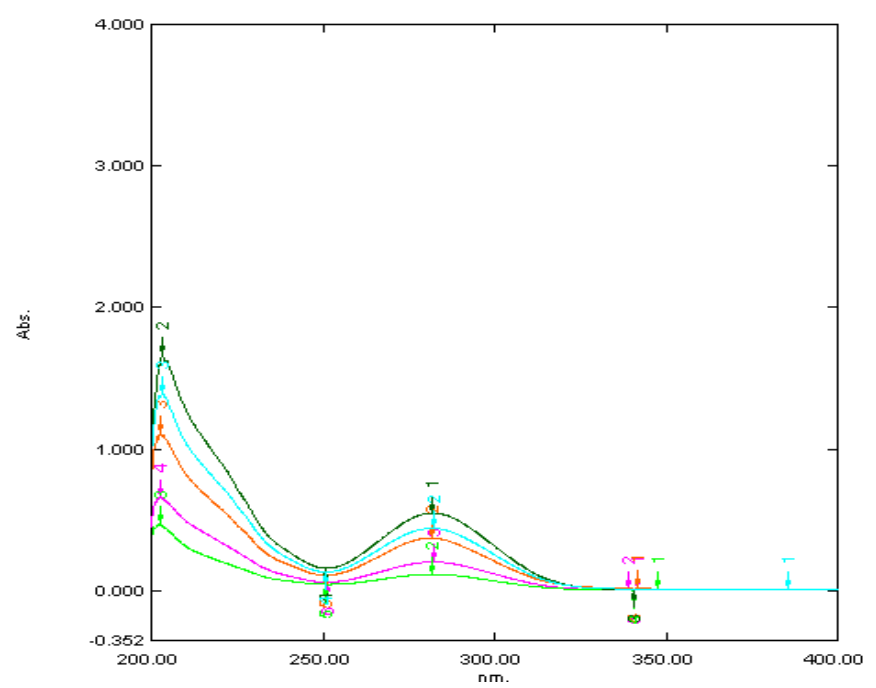

Figure 2: Azithromycin linearity absorbance spectrum

The calibration curve of azithromycin in phosphate buffer $\mathrm{pH} 6.8$ was found to be linear in the concentration range $10-50 \mu \mathrm{g} / \mathrm{ml}$ (Figure 3 ) having $\mathrm{R}^{2}$ value 0.997 .

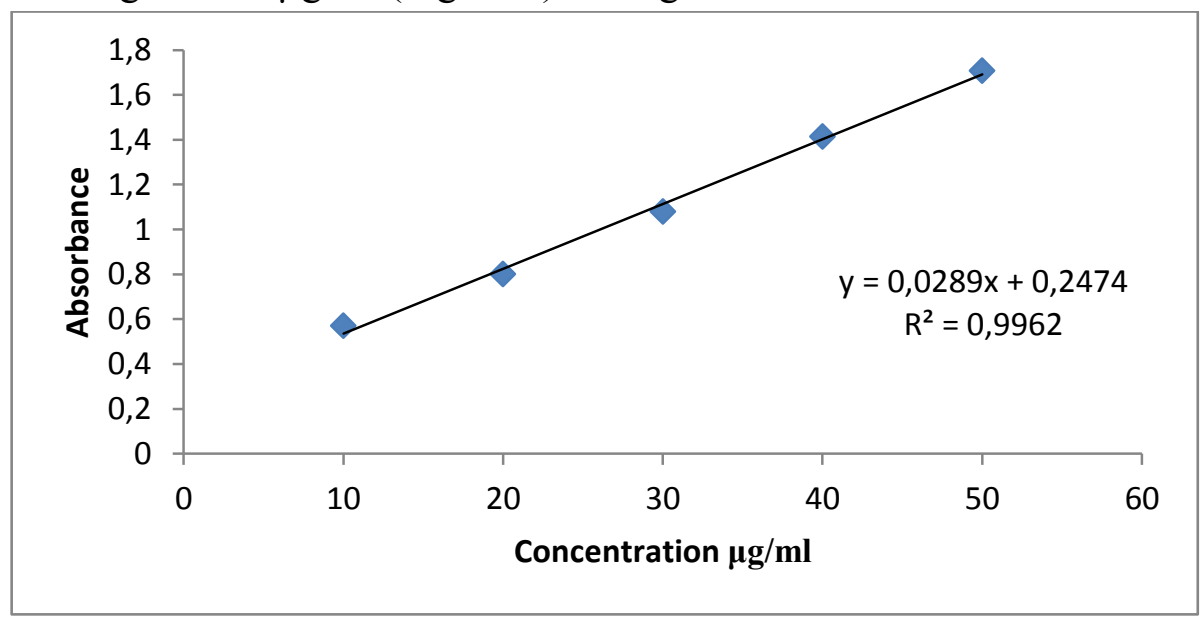

Figure 3: Calibration Curve of Azithromycin. 
The developed method is precise as the \% RSD values of intra-day (Table 1) and inter-day (Table 2) studies were found less than $2 \%$ which is acceptable by ICH requirement.

Table 1: Statistical analysis for INTRADAY ASSAY of the proposed method

\begin{tabular}{|c|c|c|c|c|c|}
\hline \multirow[t]{2}{*}{ Sr. No. } & \multirow{2}{*}{$\begin{array}{c}\text { Concentration } \\
(\mu \mathrm{g} / \mathrm{ml})\end{array}$} & \multicolumn{3}{|c|}{ Absorbance $(\lambda$ max $=208 \mathrm{~nm})$} & \multirow[t]{2}{*}{ Statistical Analysis } \\
\hline & & Sample 1 & Sample 2 & Sample 3 & \\
\hline 1 & 30 & 1.072 & 1.076 & 1.080 & \multirow{2}{*}{ Mean: $29.97(\mu \mathrm{g} / \mathrm{ml})$} \\
\hline 2 & 30 & 1.100 & 1.062 & 1.075 & \\
\hline 3 & 30 & 1.050 & 1.068 & 1.085 & \multirow{2}{*}{ SD: 0.01465} \\
\hline 4 & 30 & 1.120 & 1.080 & 1.078 & \\
\hline 5 & 30 & 1.068 & 1.075 & 1.080 & \multirow{2}{*}{$\%$ RSD: $1.36 \%$} \\
\hline 6 & 30 & 1.080 & 1.080 & 1.072 & \\
\hline
\end{tabular}

Table 2: Statistical analysis for INTERDAY ASSAY of the proposed method

\begin{tabular}{|c|c|c|c|c|c|}
\hline \multirow{2}{*}{ Sr. No. } & \multirow{2}{*}{$\begin{array}{c}\text { Concentration } \\
(\mu \mathrm{g} / \mathrm{ml})\end{array}$} & \multicolumn{3}{|c|}{ Absorbance $(\lambda$ max $=203 \mathrm{~nm})$} & \multirow{2}{*}{ Statistical Analysi } \\
\hline & & Day 1 & Day 2 & Day 3 & \\
\hline 1 & 30 & 1.045 & 1.092 & 1.10 & \multirow{2}{*}{ Mean: $29.88(\mu \mathrm{g} / \mathrm{ml}$} \\
\hline 2 & 30 & 1.090 & 1.084 & 1.090 & \\
\hline 3 & 30 & 1.068 & 1.060 & 1.072 & \multirow{2}{*}{ SD: 0.0150} \\
\hline 4 & 30 & 1.095 & 1.080 & 1.080 & \\
\hline 5 & 30 & 1.078 & 1.075 & 1.098 & \multirow{2}{*}{$\%$ RSD: $1.40 \%$} \\
\hline 6 & 30 & 1.084 & 1.063 & 1.10 & \\
\hline
\end{tabular}

The method is also specified as the \% recovery was found to be $98.21 \%$. The LOD $(1.6 \mu \mathrm{g} / \mathrm{mL})$ and LOQ $(5 \mu \mathrm{g} / \mathrm{mL})$ were performed at sub-microgram level indicating the sensitivity of the developed method. The method is also robust and rugged as the \%RSD value were less than $3 \%$. The formulation label claim meets with the clam as the performed accuracy shows the $\%$ recovery $99.91 \%$. The results of the validation parameter are shown in the Table 3 .

Table 3: Validation parameters

\begin{tabular}{ccc}
\hline Sr. no & Parameter & Result \\
\hline 1. & Absorption maxima $(\mathrm{nm})$ & $208 \mathrm{~nm}$ \\
2. & Linearity range $(\mu \mathrm{g} / \mathrm{ml})$ & $10-50 \mu \mathrm{g} / \mathrm{ml}$ \\
3. & Standard Regression Equation & $\mathrm{y}=0.0289 \mathrm{x}+0.2477$ \\
4. & Correlation coefficient $\left(\mathrm{R}^{2}\right)$ & 0.9962 \\
5. & Accuracy $(\%$ recovery $\pm \mathrm{SD})$ & $99.72 \pm 0.1081$ \\
6. & Precision $(\% \mathrm{RSD})$ & $<2 \%$ \\
7. & Specificity $(\%$ recovery $\pm \mathrm{SD})$ & $98.21 \pm 1.051$ \\
8. & LOD $(\mu \mathrm{g} / \mathrm{ml})$ & $1.6(\mu \mathrm{g} / \mathrm{ml})$ \\
9. & LOQ $(\mu \mathrm{g} / \mathrm{ml})$ & $5.0(\mu \mathrm{g} / \mathrm{ml})$ \\
\hline
\end{tabular}

The degradation studies were shown that Azithromycin undergoes degradation in acidic, alkaline and oxidation conditions; it is also less stable in UV, whereas, it was relatively stable under dry heat condition. The summary of the stress degradation studies is given in the Table 4 .

Table 4: Stress degradation study

\begin{tabular}{ccc}
\hline Condition & Time & Degradation (\%) \\
\hline $1 \mathrm{~N} \mathrm{HCl}(1 \mathrm{ml})$ & 30 minutes & $56 \%$ \\
& 60 minutes & $100 \%$ \\
& 90 minutes & $100 \%$ \\
\hline $0.1 \mathrm{~N} \mathrm{NaOH}(1 \mathrm{ml})$ & 30 minutes & $56 \%$ \\
& 60 minutes & $83 \%$ \\
& 90 minutes & $100 \%$ \\
\hline Dry heat $\left(70^{\circ} \mathrm{C}\right)$ & 48 hours & $23.74 \%$ \\
\hline $30 \%$ Hydrogen peroxide $(1 \mathrm{ml})$ & 15 minutes & $100 \%$ \\
\hline Photolytic & 12 hours & $100 \%$ \\
\hline
\end{tabular}




\section{Conclusion}

All above studies lead to the conclusion that the method developed is accurate, precise, specific, cost effective, robust, rugged, simple and sensitive. This method can be applied in the estimation of AZI bulk and in pharmaceutical formulation. The method is also applicable for the stability testing of AZI in bulk as well as in pharmaceutical dosage form.

\section{References}

[1] D. Amantea, M. Certo, F. Petrelli, C. Tassorelli, G. Micieli, M. T. Corasaniti, P. Puccetti, F. Fallarino and G. Bagetta, Azithromycin protects mice against ischemic stroke injury by promoting macrophage transition towards M2 phenotype, Exp. Neurol. 275 Pt 1 (2016) 116-125.

[2] S. Piscitelli, L. Danziger and K. Rodvold, Clarithromycin and azithromycin: new macrolide antibiotics, Clin. Pharm. 11 (1992) 137.

[3] G. Foulds, R. M. Shepard and R. B. Johnson, The pharmacokinetics of azithromycin in human serum and tissues, J. Antimicrob. Chemother. 25 Suppl A (1990) 73-82.

[4] Z. Mandić, Z. Weitner and M. Ilijaš, Electrochemical oxidation of azithromycin and its derivatives, J. Pharm. Biomed. Anal. 33 (2003) 647-654.

[5] B. Nigović and B. Šimunić, Voltammetric assay of azithromycin in pharmaceutical dosage forms, J. Pharm. Biomed. Anal. 32 (2003) 197-202.

[6] R. Gandhi, C. L. Kaul and R. Panchagnula, Validated LC method for in-vitro analysis of azithromycin using electrochemical detection, J. Pharm. Biomed. Anal. 23 (2000) 1073-1078.

[7] Z. Y. Yang, L. Wang and X. Tang, Determination of azithromycin by ion-pair HPLC with UV detection, J. Pharm. Biomed. Anal. 49 (2009) 811-815.

[8] P. Zubata, R. Ceresole, M. A. Rosasco and M. T. Pizzorno, A new HPLC method for azithromycin quantitation, J. Pharm. Biomed. Anal. 27 (2002) 833-836.

[9] P. L. Raval, F. A. Mehta, K. B. Ahir and K. K. Bhatt, Simultaneous estimation of azithromycin dihydrate and cefixime trihydrate in pharmaceutical formulation by HPTLC method, J. Liq. Chromatogr. Rel. Technol. 37 (2014) 1805-1818.

[10]B. M. Chen, Y. Z. Liang, X. Chen, S. G. Liu, F. L. Deng and P. Zhou, Quantitative determination of azithromycin in human plasma by liquid chromatography-mass spectrometry and its application in a bioequivalence study, J. Pharm. Biomed. Anal. 42 (2006) 480-487.

[11]R. V. S. Nirogi, V. N. Kandikere, M. Shukla, K. Mudigonda, S. Maurya, R. Boosi and A. Yerramilli, Sensitive and selective liquid chromatography-tandem mass spectrometry method for the quantification of azithromycin in human plasma, Anal. Chim. Acta 553 (2005) 1-8.

[12]Y. Shen, C. Yin, M. Su and J. Tu, Rapid, sensitive and selective liquid chromatography-tandem mass spectrometry (LC-MS/MS) method for the quantification of topically applied azithromycin in rabbit conjunctiva tissues, J. Pharm. Biomed. Anal. 52 (2010) 99-104.

[13] ICH, Validation of analytical procedures: text and methodology, Q2 (R1) 1 (2005) 